\title{
Carolina Leonetti
}

Centre Européen Universitaire - Université Nancy 2 (FrancJa)

Thumaczenie: Magdalena Filary, Mateusz Grzelczyk Uniwersytet im. Adama MickiewicZa w Poznaniu

\section{Świeckość państwa zakwestionowana we Wtoszech. Debata na temat krzyży w szkolnych klasach}

3 LISTOPADA 2009 R. Europejski Trybunat Praw Człowieka w Strasburgu wydat wyrok we włoskiej sprawie Lautsi, szeroko dyskutowanej $w$ europejskiej opinii publicznej. Werdykt Trybunatu zostat zakwestionowany we Włoszech zarówno przez prawicę, bliska Kościołowi katolickiemu, jak i lewicę. Włoski rząd upoważnił ministra spraw zagranicznych Franco Frattiniego do wniesienia odwołania przeciwko wyrokowi Trybunatu.

Większość Włochów uważa krzyż w większym stopniu za symbol kulturowy niż religijny. Wedtug sondażu opublikowanego przez dziennik „Corriere della Sera”, aż 84 \% Włochów akceptuje eksponowanie krzyży w szkolnych klasach, a także $w$ pomieszczeniach administracji publicznej. Najbardziej przychylne eksponowaniu krzyży sa osoby starsze, posiadajace wyksztatcenie średnie, mieszkajace $w$ regionach południowych i na wyspach oraz głosujace na partie prawicowe. Odsetek praktykujacych katolików przychylnych zachowaniu krzyży w pomieszczeniach publicznych wzróst do 93\%, natomiast $w$ środowiskach świeckich przeciwnicy krzyży stanowią tylko ok. 30\%.

Niedawny spór między świeckościa państwa a pluralizmem religijnym nie jest jednak nowym problemem w Europie.

\section{ZARYS NORMATYWNY KONFLIKTU}

OвYwAtelka WŁoch, pani Soile Lautsi, 27 lipca 2006 r. wniosła sprawę do Trybunału w Strasburgu, powołując się na art. 34 Europejskiej Konwencji o Ochronie Praw Człowieka i Podstawowych Wolności, działając w imieniu swoim, jak również dwójki swoich dzieci, Dataico i Sami Albertin, w wieku jedenastu i trzynastu lat, którzy w roku szkol- 
nym 2001 - 2002 uczęszczali do włoskiej szkoły publicznej w miejscowości Abano Terme.

Pani Lautsi uznała, iż obecność krzyży we wszystkich klasach szkoły, do której uczęszczały jej dzieci, jest sprzeczna z zasadą świeckości państwa, wolnością przekonań i religii oraz z prawem rodziców do kształcenia swoich dzieci zgodnie z własnymi przekonaniami religijnymi oraz filozoficznymi. Powołała się przy tym na art. 2 Protokołu nr 1 do Konwencji, zgodnie z którym: Nikt nie może być pozbawiony prawa do nauki. Państwo wykonując swoje funkcje $w$ dziedzinie wychowania i nauczania, uznaje prawo rodziców do zapewnienia tego wychowania i nauczania zgodnie z ich własnymi przekonaniami religijnymi i filozoficznymi, jak również art. 9 Konwencji mówiący o tym, że: Każdy ma prawo do wolności myślenia, sumienia i wyznania.

Obecność krzyży we włoskich szkołach publicznych jest konsekwencją złożonych relacji pomiędzy państwem włoskim a Watykanem, a w szczególności z procesem budowania państwa włoskiego i dążeniem do uzyskania niezależności od Stolicy Apostolskiej. W rzeczywistości bowiem obowiązek eksponowania krzyża w szkolnych klasach sięga okresu jednoczenia Włoch - zgodnie z art. 140 dekretu królewskiego nr 4336 z 15 września 1860 r. Królestwa Piemont-Sardynia każda szkoła musiała zostać zaopatrzona w krzyż.

W czasie dyktatury faszystowskiej we Włoszech szereg państwowych rozporządzeń potwierdziło obowiązek eksponowania krzyży w salach lekcyjnych. Zgodnie z art. 118 dekretu królewskiego nr 965 z 30 kwietnia 1924 r. dot. regulaminu wewnętrznego szkół średnich w Królestwie: każda placówka szkolna powinna posiadać flagę narodowa, każda klasa szkolna symbol krzyża i portret króla. Artykuł 119 dekretu królewskiego nr 1297 z 26 kwietnia 1928 r. dot. rozporządzenia ogólnego służb nauczania podstawowego, zalicza krzyż do wyposażenia i materiałów niezbędnych $w$ salach szkolnych.

\section{ZARYS HISTORYCZNY SPORU: OD ABANO TERME DO STRASBURgA}

ZGODNIE Z OPISEM SPRAWY zawartym w wyroku włoskiego sądu kasacyjnego pani Lautsi podczas zebrania szkolnego zorganizowanego przez ecoleque (rozporządzenie $\mathrm{nr} 4273 \mathrm{z} 1$ marca $2000 \mathrm{r}$.) zakwestionowała fakt obecności krzyży w klasach wykorzystywanych do głosowania podczas wyborów politycznych, co już wcześniej zostało uznane przez włoskie sądy za sprzeczne z zasadą świeckości państwa. Dyrekcja szkoły pozostawiła jednak krzyże w klasach szkolnych poza okresem wy- 
borczym, w związku z czym pani Lautsi rozpoczęła prawdziwą batalię sądową, która doprowadziła ją aż do Trybunału w Strasburgu. Podjęła ona bowiem decyzję o wniesieniu sprawy do sądu administracyjnego właściwego dla okręgu Wenecji, powołując się na pogwałcenie zasady świeckości oraz bezstronności administracji publicznej (zgodnie $\mathrm{z}$ art. 97 włoskiej konstytucji).

Według weneckiego sądu administracyjnego wniesiona sprawa dotyczyła kwestii konstytucyjnych, w związku z czym została ona odesłana do włoskiego trybunału konstytucyjnego. W czasie postępowania przed trybunałem konstytucyjnym pani Lautsi stwierdziła, iż biorąc pod uwagę prawo do nauki oraz obowiązek szkolny, obecność krzyży w klasach szkolnych została narzucona uczniom, rodzicom i nauczycielom oraz faworyzuje religię katolicką, dyskredytując tym samym inne religie. Przedstawiciel włoskiego rządu stwierdził natomiast, iż obecność krzyża w klasach jest czymś naturalnym, gdyż krzyż jest nie tylko symbolem religijnym, ale także flaga Kościoła katolickiego, który jest jedynym Kościołem wymienionym w art. 7 włoskiej konstytucji. W związku z tym, krzyż należy traktować jako symbol państwa włoskiego.

15 grudnia 2004 r. trybunał konstytucyjny stwierdzil, iż nie posiada kompetencji do rozpatrzenia sprawy odesłanej przez wenecki sąd administracyjny, ponieważ sporne rozporządzenie jest rozporządzeniem bez mocy prawnej i w konsekwencji nie podlega rozpatrzeniu przez trybunał. Pozew pan Lautsi został odrzucony przez okręgowy trybunał administracyjny wyrokiem z 17 marca 2005 r., w którym trybunał administracyjny uznał, iż krzyż stanowi symbol historii, kultury i tożsamości włoskiej, symbol równości, wolności, tolerancji i świeckości państwa. Wobec tej decyzji pani Lautsi wniosła odwołanie do włoskiej Rady Stanu, która wyrokiem z 13 lutego 2006 r., odrzuciła jej pozew, stwierdzając, iż krzyż stał się jedną z wartości świeckich sankcjonowanych przez konstytucję włoską i reprezentuje wartości życia obywatelskiego.

Włoskie sądy kolejnych instancji uznały, że dwa w/w rozporządzenia zawsze obowiązywały i należało je stosować, tym bardziej, że były wcześniejsze od Traktatów laterańskich z 1929 r. oraz od przyjętej w 1948 r. konstytucji republikańskich Włoch. Chodzi w szczególności o dziedzictwo pewnej koncepcji wyznaniowej państwa, która została wyraźnie odrzucona dopiero w 1985 r., na mocy Protokołu dodatkowego do nowych umów ze Stolicą Apostolską. 
Przed Trybunałem w Strasburgu pani Lautsi utrzymywała, iż eksponowanie krzyży w klasach włoskich szkół publicznych przyznaje religii katolickiej uprzywilejowaną pozycję, co oznacza nie tylko ingerencję państwa w podstawowe wolności: przekonań, sumienia i religii, ale również pogwałcenie prawa rodziców do kształcenia swoich dzieci zgodnie z własnymi przekonaniami moralnymi i religijnymi. Według niej jest to również dyskryminacja nie-katolików, ponieważ krzyż budzi przede wszystkim skojarzenia religijne, które dają uczniom poczucie, że państwo włoskie przynależy do określonej wiary religijnej.

Przedstawiciel rządu włoskiego w czasie postępowania przed Trybunałem przyznał, iż poruszona kwestia ma w większym stopniu charakter filozoficzny niż prawny. Krzyż, początkowo symbol wyłącznie religijny, współcześnie nabiera również znaczenia etycznego i historycznego, przypominając o wartościach, które nie są wyłącznie związane $\mathrm{z}$ wiarą chrześcijańską, jak choćby potępienie przemocy, poszanowanie godności wszystkich ludzi, sprawiedliwość i równość, miłość do bliźniego i przebaczenie nieprzyjaciołom. Fundamenty współczesnej demokracji liberalnej zostały oparte na przesłaniu ewangelickim, krzyż stał się natomiast uniwersalnym znakiem humanizmu oraz symbolem zasad i wartości, które stanowią podstawę naszej demokracji.

Zdaniem włoskiego rządu obecność krzyża nie stanowi więc żadnego naruszenia świeckości państwa, czy też praw i wolności, zagwarantowanych przez Europejską Konwencję Praw Człowieka. Argumentacja włoskiego rządu jest zgodna z linią orzecznictwa Trybunału w Strasburgu, który, dla stwierdzenia naruszenia podstawowych praw i wolności, wymaga dużo bardziej aktywnej ingerencji. Obecność krzyży w klasach włoskich szkół nie jest równoznaczna z żądaniem dla tego symbolu jakiegokolwiek znaku pozdrowienia, wyrazu szacunku czy też obowiązku odmawiania wspólnych modlitw w klasie. Nie ulega wątpliwości, iż włoski system szkolnictwa jest całkowicie świecki i pluralistyczny, uczęszczanie na lekcje religii nie jest obowiązkowe, a programy szkolne nie zawierają żadnych odniesień do konkretnej religii. Krzyż jest zatem tylko symbolem przypominającym o włoskiej tradycji kulturowej i o wartościach ludzkich wyznawanych prze innych chrześcijan.

Co więcej, władze państwowe korzystają z dużego marginesu swobody w tej kontrowersyjnej kwestii związanej nierozłącznie z historią i kulturą - przykładowo w Grecji, wszystkie uroczystości o charakterze cywilnym i militarnym przewidują obecność oraz aktywne uczestnictwo ministra ds. religii prawosławnej, a w Wielki Piątek, czy też 
w przypadku ogłoszenia żałoby narodowej, wszystkie biura i sklepy są zamknięte, podobnie zresztą jak we francuskiej Alzacji. Wybór, czy zachować krzyż w przestrzeni publicznej, czy też nie, zależy w większym stopniu od przyjętej polityki, niż od kryterium zgodności z prawem.

\section{Stanowisko Trybunaeu w Strasburgu}

Trybuną w Strasburgu stwierdził, iż zgodnie z art. 2 Protokołu Europejskiej Konwencji Praw Człowieka państwo w wykonywaniu zadań w dziedzinie edukacji i szkolnictwa podejmuje się ochrony pluralizmu edukacyjnego, głównie ochrony społeczności demokratycznej. Instytucje szkolnictwa publicznego powinny być zatem otwarte i sprzyjać integracji uczniów niezależnie od ich pochodzenia społecznego, przekonań religijnych czy też pochodzenia etnicznego. Szkoła powinna być miejscem spotkań różnych religii i przekonań filozoficznych. Natomiast zgodnie z drugim zdaniem art. 2 Protokołu nr 1 państwo zobowiązane jest do czuwania nad tym, aby programy szkolne były obiektywne, krytyczne i pluralistyczne nie miały na celu wpajania uczniom jakichkolwiek poglądów. Tym samym szacunek do przekonań religijnych rodziców i dzieci pociąga za sobą prawo do tego, by nie wierzyć w żadną religię.

Według Trybunału, państwo musi powstrzymać się od narzucania przekonań, nawet w sposób niebezpośredni, w miejscach, w których obywatele są od państwa w jakikolwiek sposób zależni lub gdzie są oni szczególnie narażeni na narzucanie przekonań. Szkolnictwo podstawowe może zostać uznane właśnie za takie miejsce, ponieważ dzieci dysponują mniejszą zdolnością krytycznego myślenia niż osoby dorosłe.

Trybunał przyznał również, iż symbol krzyża ma więcej niż tylko jedno znaczenie, niemniej jednak skojarzenie religijne jest dominujące. Jeśli zaś chodzi o wpływ krzyża na młodych uczniów, uznaje się, iż w krajach, w których większość populacji przystępuje do danej religii, manifestowanie obrzędów i symbolów tej religii może wywołać presję na uczniów, którzy nie praktykują wspomnianej religii lub na tych, którzy przynależą do innej religii.

Obecność krzyża w klasach szkolnych może zostać odebrana przez uczniów jako znak religijny, co spowoduje, iż będą się oni czuli wykształceni w środowisku szkolnym, naznaczonym przez daną religię. Takiej sytuacji nie można usprawiedliwić ani prośbą innych rodziców, którzy oczekują edukacji religijnej zgodnej z ich przekonaniami, ani stwierdzeniem rządu o konieczności niezbędnego kompromisu z par- 
tiami politycznymi o poglądach chrześcijańskich. Państwo musi zagwarantować neutralność wyznaniową w ramach szkolnictwa publicznego, którego zadaniem jest wykształcenie u uczniów umiejętności krytycznego myślenia.

Trybunał nie dostrzegł związku, w jaki sposób krzyż, słusznie kojarzony z katolicyzmem, który stanowi religię dominującą we Włoszech, może służyć pluralizmowi edukacyjnemu, który jest istotny w ochronie spoteczeństwa demokratycznego, zgodnie z Konwencją i powoduje ograniczenie prawa rodziców do kształcenia swoich dzieci według własnych przekonań, tak samo jak praw dzieci objętych nauczaniem szkolnym do tego, by wyznawać jakąkolwiek wiarę bądź nie.

KRZYŻE W SZKOŁACH PUBLICZNYCH: PRAWDZIWIE EUROPEJSKIE PYTANIE

27 STYCZNIA 2009 R. sąd administracyjny w Lille (Francja) wydał wyrok w sprawie uczniów z Wandignies-Hamage, którzy każdego popołudnia spożywali posiłek u stóp wielkiego krzyża umieszczonego w refektarzu, który był dawną salą katechetyczną, a stał się szkolną jadalnią. Sąd zobowiązał lokalne merostwo do postępowania w imię poszanowania bezstronności - w konsekwencji przygotowano specjalny plakat, by zakryć krzyż i w zależności od wieku osób przebywających w tej sali, krzyż jest odkryty lub przykryty plakatem. Art. 28 francuskiej ustawy z 5 czerwca 1905 r. o separacji Kościoła od państwa określa bowiem, iż: W przyszłości jest zakazane wznoszenie lub przyklejanie jakiegokolwiek znaku lub symbolu religijnego na budynkach publicznych lub placach budowy, co dotyczy nie tylko merostw czy francuskich szkół publicznych, ale również wejść na cmentarze, a nawet nagrobków zmarłych. Jedynie Alzacja i departament Moselle w Lotaryngii uzyskały odstępstwa, ponieważ te dwa terytoria nie należały do Francji w momencie przyjęcia ustawy o rozdziale Kościoła od państwa, dlatego w tych dwóch przypadkach ustawa ta nie znajduje zastosowania, ponieważ w/w terytoria podlegają systemowi konkordatowemu z $1801 \mathrm{r}$. dot. znaków religijnych w szkole.

22 października 2003 r. na wniosek obywatela włoskiego, Adela Smitha, przewodniczącego związku muzułmanów we Włoszech, sąd nakazał dyrektorowi szkoły zdjęcie krzyży z sal przedszkola i szkoły podstawowej, do których uczęszczali jego synowie. Ta decyzja nigdy nie została jednak wykonana, ponieważ najpierw została zawieszona przez przewodniczącego sądu, a następnie zmieniona ze względu na brak kompetencji sądu do zajmowania się powyższą sprawą. W innej sprawie, w lutym 2009 r., Franco Cappoli, nauczyciel publiczne- 
go liceum zawodowego został zawieszony na miesiąc za systematyczne zdejmowanie krzyża ze ściany podczas swoich zajęć.

W Hiszpanii, kraju tradycyjnie bardzo katolickim (chociaż według sondażu opublikowanego na początku listopada 2008 r. przez dziennik „El Pais”, 21 \% Hiszpanów uważa się za dość lub bardzo religijnych, a do $47 \%$ wcale lub mało religijnych) w 2008 r. sąd administracyjny w Valladolid nakazał szkole publicznej zdjęcie krzyży, na wniosek rodziców jednego z uczniów, poparty przez Associación Cultural Escuela Laica de Valladolid, złożony w 2005 r. Rodzice ucznia wcześniej kilka razy prosili o zdjęcie krzyży, ale rada szkolna w drodze głosowania wypowiedziała się w sposób negatywny. Sąd w Valladolid wyjaśniał swoją decyzję, stwierdzając, iż obecność tych symboli w pomieszczeniach wspólnych publicznego ośrodka edukacyjnego, w których osoby małoletnie sq nauczane, może u nich spowodować wrażenie, że państwo jest bliżej katolicyzmu niż innych wyznań religijnych.

W Austrii zgodnie z ustawą na temat edukacji religijnej w szkole, potwierdzonej w trzecim Konkordacie zawartym ze Stolicą Apostolską, dyrektorzy austriackich szkół publicznych są zobowiązani do umieszczenia krzyża w każdej klasie, gdzie więcej niż połowa uczniów jest katolikami. W niemieckiej Bawarii krzyże obecne są również w domach starców, szpitalach, hotelach, restauracjach. W słynnej aferze krzyżowej niemiecki trybunał konstytucyjny 16 maja 1955 r. wypowiedział się na temat zgodności wolności religijnej z obowiązkiem zawieszenia krzyży w klasach szkół publicznych w Bawarii. Trybunał uznał, iż krzyż stanowi nie tylko symbol wiary, ale również symbol kulturalny tego regionu, jednakże nauka pod krzyżem z pewnością narusza wolność religijną. Na skutek tej decyzji 23 grudnia 1955 r. Bawaria przyjęła nowelizację ustawy o systemie edukacji, w której nadała szczególnie znaczenie obecności krzyży z powodu historii i własnej kultury Bawarii, dodając, iż jeśli obecność krzyża poważnie narazi wolność sumienia jakiegokolwiek ucznia, obowiązkiem dyrektora tejże szkoły, jest znalezienie polubownego rozwiązania. W przypadku braku porozumienia, dyrektor podejmuje decyzję, biorąc pod uwagę oczekiwania stron, zaspokajając wolność sumienia i przekonań religijnych w instytucjach szkolnych, ale biorąc zarazem pod uwagę w miarę możliwości wolę większości.

\section{CZekając na ostateczną Decyzję Strasburga...}

Debata we WŁoszech na temat kRzyŻy pozostaje nadal otwarta. Warto wspomnieć, iż premier Włoch Silvio Berlusconi zapewnił Stolicę Apo- 
stolską, iż decyzja Trybunału w Strasburgu nie jest właściwa. I w tym przypadku, i rząd, i opozycja we Włoszech są ze sobą zgodne.

\section{SUMMARY}

In November 2009 the European Court of Human Rights in Strasbourg ruled that crosses displayed in classrooms of public school are not in agreement with the freedom of religion guaranteed by the European Convention on Human Rights. This ruling was based on the claim that the presence of the Christian symbol limit parents' right to educate their children in conformity with their own faith and the right of children to believe or not to believe. In Italy, from which the case originates, the Court's sentence stirred up heated political debates and caused strong public opinion reactions. The verdict was interpreted as a threat to the Catholic-based cultural traditions of the country, despite the traditions not being continued in terms of religious devotion in Italy.

\section{NOTY O AUTORACH}

Carolina Leonetti (wł.) - studentka europeistyki na poziomie Master $1 \mathrm{w}$ Centre Européen Universitaire w Nancy, studia prawnicze na poziomie licencjackim ukończone na Università „Magna Graecia” di Catanzaro (Włochy).

Magdalena Filary [aragaze@wp.pl] - magister filologii rumuńskiej (Wydział Neofilologii UAM Poznań).

Mateusz Grzelczyk [mateusz.grzelczyk@gmail.com] - student V roku politologii na Wydziale Nauk Politycznych i Dziennikarstwa UAM w Poznaniu oraz europeistyki w Centre Européen Universitaire w Nancy w ramach stypendium LLP Erasmus. 